\title{
УДОСКОНАЛЕННЯ МАЛОЇ МЕХАНІЗАЦІЇ В ТЕХНОЛОГІЇ ВИРОЩУВАННЯ КАРТОПЛІ НА ПРИСАДИБНИХ ДІЛЯНКАХ
}

\section{Рецензент - кандидат технічних наук В. М. Сакало}

\begin{abstract}
Підвищення урожайності картоплі можливе за рахунок збільшення в осінньо-зимовий період кількості накопиченої в трунті вологи, (в прошарку нижче розташування коріння рослин). Існуючі технології обробітку грунту присадибних ділянок не забезпечують накопичення вологи в достатній кількості та збереження ї̈ під час вегетації картоплі. Запропоновано технічне вирішення проблеми із використанням засобів малої механізаиії оснашеними робочими органами удосконаленої конструкиії. Наведено рекомендовану схему для виконання технологічного процесу «кротування» грунту на присадибних ділянках.
\end{abstract}

Ключові слова: присадибна ділянка, трунт, кротування, мотоблок, обробіток трунту, робочі органи.

Постановка проблеми. Основною культурою, що переважає на присадибних ділянках мешканців України, є картопля. За останні роки клімат на території України й Полтавщини зокрема змінився на пом'якшений. Підтвердженням цього $є$ малосніжні зими та посушливі літні періоди, під час яких температура досягає на окремих територіях близько $+35^{\circ} \mathrm{C}$. Внаслідок цього дачники зустрічаються 3 проблемою недостатнього зволоження грунту, що позначається на урожайності овочів. Одним зі шляхів вирішення проблеми $є$ примусовий полив, або дощування, негативним наслідком такої технології $є$ ущільнення поверхневого шару грунту, утворення поверхневої кірки та інтенсивного випаровування вологи з верхніх шарів ділянки. Порушення водного балансу призводить до поступового зниження врожайності сільськогосподарських культур, зокрема й картоплі, а також зменшує родючість грунту на присадибних ділянках.

Одним із поширених способів основного обробітку грунту є оранка. Встановлено, що в процесі вирощування сільськогосподарських культур, зокрема для присадибних ділянок, така технологія обробітку має більше негативних наслідків аніж переваг [5]. Слід зазначити, що останнім часом середньостатистичний розмір оброблюваної присадибної ділянки наділу не перевищує 10 соток. За таких умов ускладнюється заїзд великогабаритної (промислової) техніки для передпосадкового обробітку грунту. Однотипний обробіток (оранка) чи ручне перекопування, навіть із використанням засобів малої механізації (мотоблоків), укомплектованих фрезерними робочими органами, призводить до утворення ущільненого підорного прошарку грунту. В наслідок цього значно погіршується проникнення вологи, порушується водно-повітряний режим грунту та ареал життєдіяльності мікроорганізмів у ньому. Тому накопичення зимово-весняної вологи в грунті та її збереження до періоду вегетації сільськогосподарської культури, ефективне їі використання залишається основною проблемою власників присадибних ділянок.

Використовуючи на присадибних ділянках мобільні малогабаритні енергетичні засоби (мотоблоки, мотокультиватори), з'явилася можливість впровадження на їх основі грунтообробних знарядь, призначених для виконання безвідвального обробітку грунту, що сприяють накопиченню й збереженню вологи. Технологія обробітку потребує розширення номенклатури начіпних знарядь, удосконалення існуючих і розробки нових конструкцій з метою підвищення урожайності овочевих сільськогосподарських культур на присадибних ділянках.

Аналіз основних досліджень і публікацій, у яких започатковано розв'язання проблеми. Останнім часом вирішенню проблеми переущільнення грунту надається чимало уваги. Роботи ведуться в напрямі використання безвідвального обробітку грунту 3 періодичним заглибленням робочих органів із метою руйнування ущільненого грунтового прошарку. Такі операції дозволяють зменшувати щільність родючого шару грунту та його засоленість внаслідок кращого проникнення вологи в осінньо-зимовий період, у процесі зрошування, збільшують його газопроникність, покращують агрофізичні властивості. 


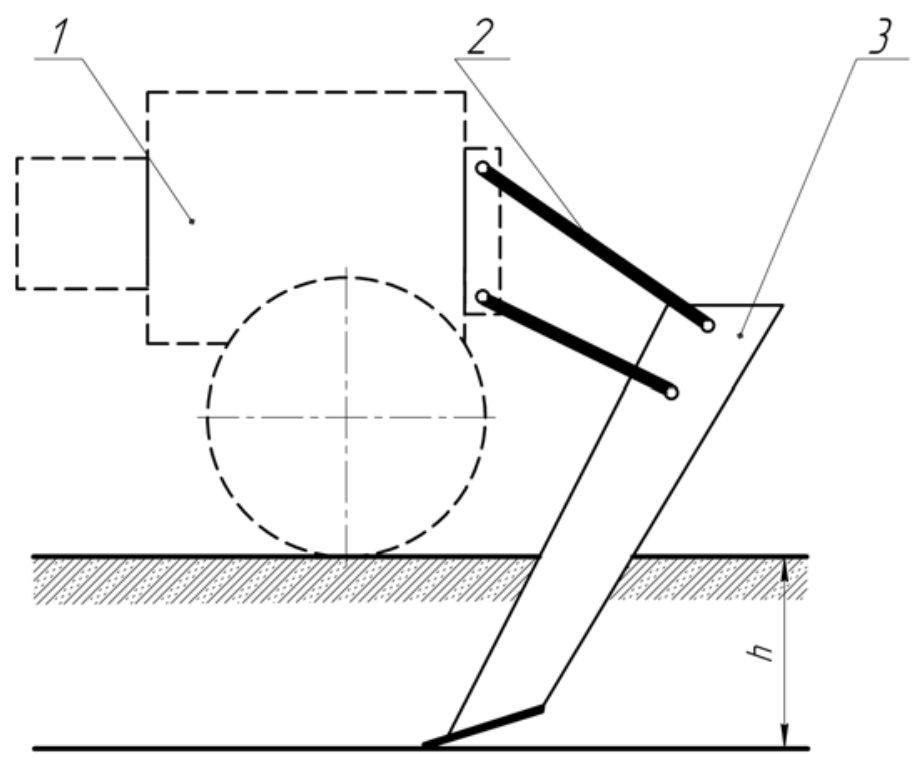

Рис. 1. Конструктивна схема глибокорозпушувача трунту для присадибних ділянок: 1 -мотоблок; 2 - зчіпний механізм; 3 -робочий орган; $h$ - глибина обробітку

Спираючись на результати наукових досліджень відомих вчених, зокрема, академіків I. І. Артоболевського [1], В. О. Желіговського [4], П. М. Василенка [3], докторів технічних наук О. В. Верняєва, Л. Ф. Бабицького [2], І. М. Панова [6], П. П. Карпуші, Г. О. Рябцева, М. В. Краснощокова та інших, нами запропонована конструкційна схема робочого органу (рис. 1) [1]:

Переваги конструкції - безвідвальний обробіток грунту; ефективне руйнування ущільнених прошарків його підорного шару; інтенсивне накопичення вологи в щілинах, що утворилися в результаті обробітку.

До недоліків слід віднести:

1) завантаження енергетичного джерела (мотоблок) лише на $55 \%$;

2) порушення стабільності руху по глибині обробітку.

Мета і завдання досліджень. Мета: підвищення врожайності картоплі шляхом утворення у грунті додаткових волого-акумулюючих каналів. Основними завданнями досліджень є: проаналізувати технології та технічні засоби для безвідвального обробітку грунту; розробити конструкцію робочого органу для накопичення вологи в грунті; встановити раціональні значення параметрів та режимів роботи робочого органу, обгрунтувати технологічну схему обробітку грунту при вирощуванні картоплі.

Матеріали і методи досліджень. Технологія розроблена з використанням основних положень землеробської механіки, механіки суцільного середовища, механіки руйнування. Обгрунту- вання параметрів робочих органів здійснювалося 3 використанням існуючих та нових методів експериментальних досліджень. Використана методика планування багатофакторного експерименту. Результати експериментальних досліджень оброблено з використанням положень математичної статистики. Агротехнічна й енергетична оцінки проводилися 3 використанням галузевих стандартів.

Результати польових досліджень. За результатами проведених у 2011-2012 рр. досліджень на присадибних ділянках глибокорозпушувача (рис. 1) встановлено, що запропонована конструкція забезпечує руйнування ущільнених прошарків грунту, утворює на поверхні щілини 2,5-3,5 см, що сприяють інтенсивному накопиченню вологи в нижніх грунтових горизонтах. Доведений ефект природного розущільнення грунту, суть якого полягає у тому, що вода, яка накопичується в осінній період у щілинах грунту, замерзає взимку, одночасно розширюючись, утворює розгалужену мережу тріщин (природне розпушення грунту). Відтаючи у весняний період, тріщини наповнюються додатковою вологою, внаслідок чого відбувається рівномірне вологонакопичення поверхневого шару глибиною близько 35сантиметрів.

Iз метою встановлення впливу запропонованої технології обробітку з використанням розробленого знаряддя на урожайність картоплі навесні 2012 року нами був закладений польовий дослід. Смуговим способом посаджені 10 рядків картоплі сорту Беллароза, п'ять із яких розміщувалися 
по лінії попередньо нарізаних восени щілин, а інші - на контрольній ділянці без осіннього обробітку. Дослідження показали, що ряди картоплі, посаджені по лінії щілин, дали дружні сходи на 5-8 днів раніше від контрольної ділянки. Розвиток кущів картоплі в умовах посушливого літа 2012 року підтвердив припущення про те, що додаткова волога, накопичена у щілинах, кореневою системою рослин використовується ефективніше. Урожайність картоплі, що вирощувалася за допомогою експериментальної методики, на 14 \% вища порівняно 3 традиційною технологією, застосованою на контрольній ділянці.

За результатами попередніх польових досліджень висунута гіпотеза: для підвищення урожайності картоплі шляхом створення у грунті додаткових волого-акумулюючих каналів необхідно удосконалити конструкцію запропонованого робочого органу (рис. 1) додатковим пристосуванням для утворення каналів у грунті. За відомими теоретичними розрахунками [5] виготовлено експериментальний робочий орган для утворення волого-акумулюючих каналів у підорному шарі (рис. 2).

Глибокорозпушувач грунту «Кріт» призначений для утворення вологоакумулюючих каналів у грунті на глибині 0,2-0,3 м від поверхні грунту круглого перерізу (подібних до кротових ходів) діаметром від 4 до 10 см на відстані 0,7-1,4 м

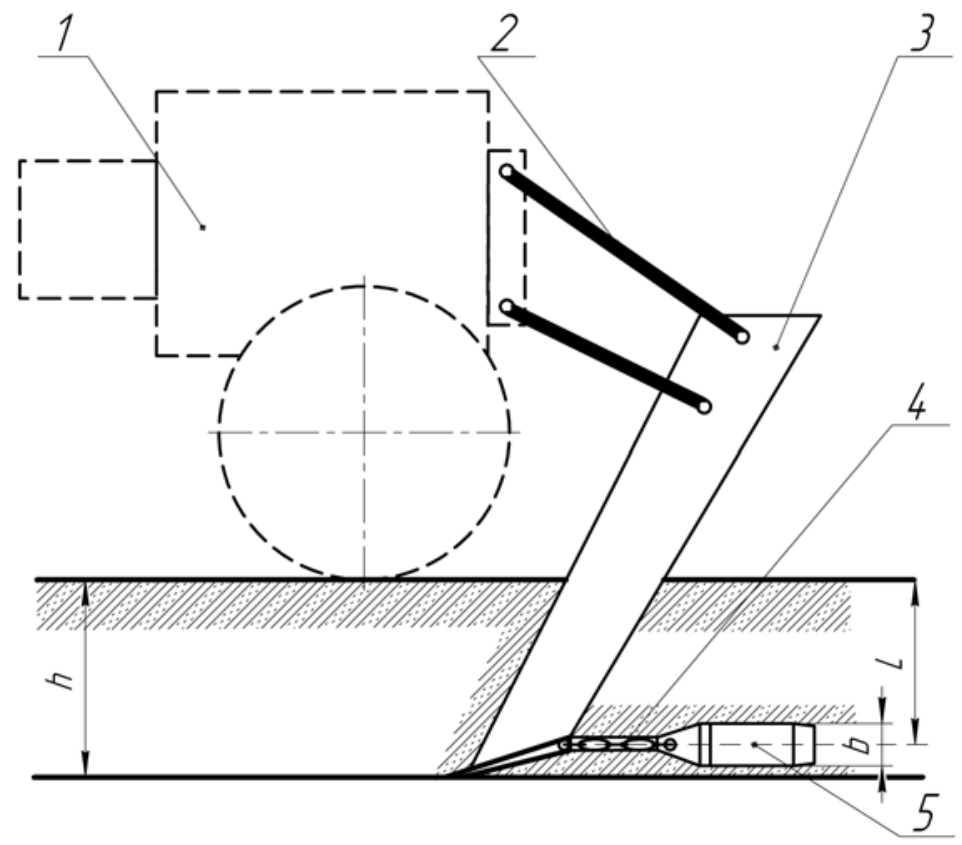

Рис. 2. Конструктивна схема глибокорозпушувача грунту «Кріт» для присадибних ділянок: один від одного. Запропонована технологічна операція проведена з використанням мотоблоку ZIRKA IZ 105, із двигуном KM178F (одноциліндровий, чотирьохтактний дизель із повітряним охолодженням та потужністю 4,41 кВт). Основний робочий орган машини - ніж (3), до нижньої частини якого шарнірно приєднаний «Кріт» (5). Передня частина «Крота» конічна, середня - циліндрична. Під час роботи ніж розрізає грунт на встановлену глибину, а «Кріт» конічною частиною розсуває та ущільнює грунт, утворюючи прохід круглого перерізу. Середня циліндрична частина формує відповідний переріз проходу. Нарізання підгрунтових проходів розпочинають iз відкритого каналу за рекомендованою схемою, представленою на рисунку 3.

Така схема руху грунтообробного агрегату дає змогу нарізати підгрунтові проходи 3 осені для максимального їх заповнення водою в осінньозимовий період, сприяючи природному, більш об'ємному, порівняно $з$ уже досліджуваним способом (рис. 1), розущільненню грунтових прошарків. Крім того, використовуючи мітки проходів (стовпчики) на краю присадибної ділянки після весняного поверхневого обробітку грунту (рис. 3), необхідно провести посадку картоплі чітко в напрямку нарізаних щілин, що в результаті забезпечить приріст урожайності на 10-15 \%

\footnotetext{
1 -мотоблок; 2 - зчіпний механізм; 3 -робочий орган; 4 -ланцюг;
$5-$-утворювач каналу «Кріт»; $h$ - глибина обробітку; $b$ - діаметр каналу;

1 -мотоблок; 2 - зчіпний механізм; 3 -робочий орган; 4 -ланцюг;
$5-$-утворювач каналу «Кріт»; $h$ - глибина обробітку; $b$ - діаметр каналу;

$L$ - відстань від поверхні трунтового горизонту до вісі каналу
}

L відстань від поверхні грунтового горизонту до вісі каналу 


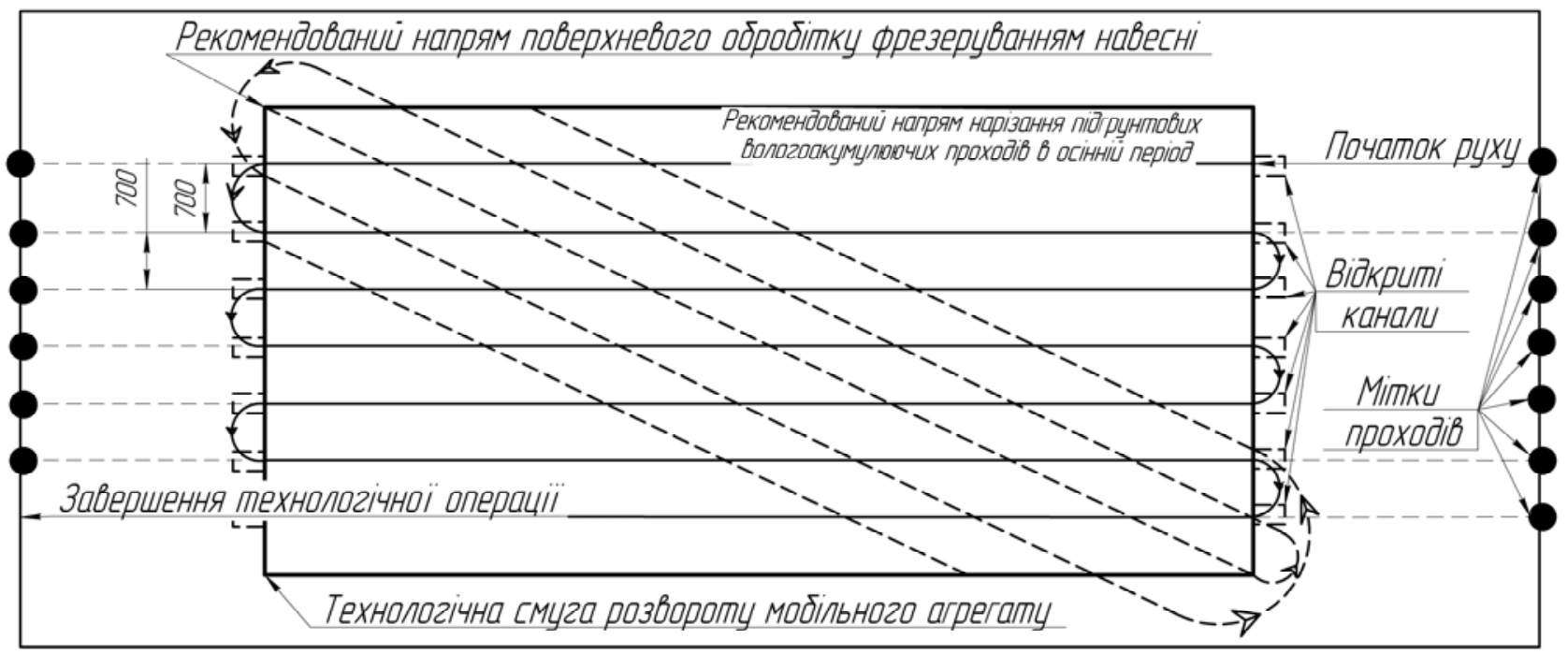

Рис. 3. Схема обробітку ділянки трунту під посадку картоплі з запропонованою технологією

порівняно з уже досліджуваним способом (звичайне щілювання) за рахунок збільшеного об'єму вологи у грунті та ефективного ії використання кореневою системою рослин. Для збереження вологи від випаровування у весняно-літній період рекомендовано на присадибній ділянці замульчувати гребені, що утворилися після посадки картоплі шаром 5-10 сантиметрів. В якості мульчі доцільно використовувати подрібнену солому зернових культур витриману 1-3 роки.

\section{Висновки:}

1. На основі аналізу існуючих технологій i технічних засобів для безвідвального обробітку встановлено, що для якісного розущільнення та розпушування грунту природним шляхом робочі органи малої механізації повинні забезпечувати нарізання щілин на глибину більшу на 5-10 см від традиційного обробітку.

2. Перспективним напрямом вирішення поставленої задачі накопичення вологи в грунті є використання глибокорозпушувача грунту «Кріт» для

\section{БІБЛІОГРАФІЯ}

1. Артоболевский И. И. Теория механизмов и машин / И. И. Артоболевский. - М. : Наука, 1988. -639 c.

2. Бабииький Л. Ф. Деформація грунту залежно від форми робочого органу / Л. Ф. Бабицький / Вісник с.-г. науки. - 1978. - № 6. - С. 84-87.

3. Василенко П. М. Теория движения частиц по шероховатым поверхностям сельскохозяйственныХ машин / П. М. Василенко. - К. : УАСХН, 1960. $-284 \mathrm{c}$.

4. Желиговский В. А. Элементы теории сельскохозяйственных машин и механической технологии присадибних ділянок, що має здатність утворювати підгрунтові проходи на глибині $0,2-0,3$ м, діаметром 4-10 см, із можливістю регулювання заданих величин залежно від вирощуваних культур.

3. Встановлено, що за раціональних значень глибини нарізання щілин $h=0,30-0,35$ м, відстані від поверхні грунтового горизонту до вісі каналу $L=0,20-0,25 \mu$, діаметра «Крота» $d=$ $0,05-0,07 \mu$ та відстані між проходами $l=0,6-0,7 \mu$ у кінцевому результаті підвищиться урожайність картоплі на 20-28 \% порівняно $з$ класичною технологією iї вирощування на присадибних ділянках.

4. Розроблено й обгрунтовано схему обробітку грунту, рекомендовану нами для вирощування картоплі на присадибних ділянках, використання якої (за умови застосування мульчі на поверхні після посадки бульбоплодів) зменшує на $25 \%$ трудові затрати на полив, боротьбу з бур'янами та сприяє підвищенню родючості грунту на присадибних ділянках без додаткових капіталовкладень.

сельскохозяйственных материалов / $\mathrm{B}$. А. Желиговский / Тбилиси : СХИ, 1960. - С. 112-115.

5. Падалка В. В. Обробіток присадибних ділянок глибокорозпушувачем грунту / Падалка В. В., Ляшенко С. В. / Збірник тез доповідей конференції професорсько-викладацького складу аграрно-інженерного інституту за підсумками наукової роботи 2011-2012 рр. - Полтава : ПДАА, 2012. $-124 \mathrm{c}$.

6. Панов И. М. Основные пути снижения энергозатрат при обработке почвы // Тракторы и сельхозмашины. - 1987. - №8. - С. 27-30. 